\title{
ROLE OF ADVANCED GLYCATION END PRODUCTS IN THE ONSET OF DIABETIC KIDNEY DISEASE COMPLICATIONS
}

\author{
Maria Luiza Almeida de Paula1 ${ }^{1}$ Ana Marina Rodrigues Villela ${ }^{1}$, \\ Mauricio Massucati Negri' ${ }^{1}$, Salim Kanaan², \\ Luciene de Carvalho Cardoso Weide ${ }^{2}$
}

\begin{abstract}
Advanced glycation end products are known to play an important role in diabetes complications, such as diabetic nephropathy. Most known pathways of diabetic complications involve oxidative stress, that have pivotal role in cell dysfunction onset and progression of angiopathies. This review will explore how AGEs cause endothelial dysfunction in diabetes and what current biochemical mechanisms have been proposed as an explanation for the development of diabetic nephropathy.
\end{abstract}

Keywords: Type 2 diabetes mellitus; advanced glycation end products; endothelial dysfunction; hyperglycemia; oxidative stress; vascular complication; diabetic nephropathy

The prevalence of diabetes mellitus (DM) has risen to epidemic proportions worldwide. The number of cases of diabetes is projected to reach 360 million people in $2030^{1,2}$. Diabetes is a chronic disease characterized by elevated blood sugar levels due to lack of insulin production (type 1diabetes-T1DM), insulin resistance (type 2 diabetes-T2DM) or both, among other mechanisms. T2DM represents $90 \%$ of the cases, implicated in insulin resistance and progressive $\beta$-cell dysfunction and loss of insulin release, leading to increasing blood glucose concentrations ${ }^{3,4}$. The consequences of uncontrolled glycemic levels are often related to diabetic chronic complications which include microvascular (nephropathy, retinopathy and neuropathy) and macrovascular disease (stroke and atherosclerosis). Thus, cardiovascular complications have the worst prognostic as they are associated with high morbidity and mortality, being the main cause of death ${ }^{5,6}$. Moreover, diabetic nephropathy $(D N)$ is a representative disorder of chronic kidney disease (CKD) and the leading cause of end-stage kidney disease (ESKD) ${ }^{7-10}$. Thus, prevention of the development and progression of this disorder is of clinical importance to improve prognosis in diabetic patients.

The diagnosis of DM has been based on fasting glycemia $\geq 126 \mathrm{mg} / \mathrm{dl}$; 2 hours glycemia, after $75 \mathrm{~g}$ oral glucose $\geq 200 \mathrm{mg} / \mathrm{dl}$; hemoglobin A1c (HbA1c) $\geq 6,5 \%$ on at least two occasions or plasma glucose levels $\geq 200 \mathrm{mg} / \mathrm{dl}$ in patients with classic symptoms of hyperglycemia or hyperglycemic crises ${ }^{11}$.

The diagnosis of diabetic nephropathy is based on the presence of proteinuria, divided into two stages: micro- and macroalbuminuria with or without loss of glomerular filtration rate ${ }^{12,13}$. Microalbuminuria is an early indicator of renal impairment. Albumin is present in large amounts in the blood, but almost none is excreted in the urine when renal function is normal. However, when kidney disease ends, urinary albumin levels rise $(30-300 \mathrm{mg} / 24 \mathrm{~h})$ and higher amounts of protein in urine reflect higher degrees of renal insufficiency ${ }^{12,14}$. Being a small molecule, albumin is one of the first proteins detected in the urine when there is kidney damage. Patients with microalbuminuria have higher risk of developing progressive renal failure in the future ${ }^{13-16}$. Macroalbuminuria is defined for urinary excretion of albumin $\geq 300 \mathrm{mg} / 24$ hours $^{17}$. Albuminuria can be estimated by 24 hours urine collection or at a random time after at least
Clin Biomed Res. 2017;37(4):341-348

1 Medical School, Universidade Federa Fluminense (UFF). Niteroi, RJ, Brazil.

2 Medical School, Department of Pathology, Universidade Federal Fluminense (UFF). Niteroi, RJ, Brazil.

Corresponding author: Luciene de Carvalho Cardoso Weide lucienecardoso@gmail.com Department of Pathology, Universidade Federal Fluminense (UFF) Avenida Marquês do Paraná 303, sala 4. 24030-215, Niteroi, RJ, Brazil. 
4 hours without urine excretion. As the concentration (or dilution) of urine varies during the day, urine creatinine levels that are stably excreted can be used as a correction factor for random urine samples ${ }^{18}$. It is considered the test of choice for screening for microalbuminuria using the albumin/creatinine urinary ratio ${ }^{11}$.

Although the consequences of the uncontrolled glycemic levels are well known, the relationship between hyperglycemia and the onset of diabetes complications is not totally clarified. Evidence suggests that it is associated with advanced glycation end-products (AGEs) formation, leading to cellular dysfunction ${ }^{19-21}$. In this review, we will consider the consequences of AGEs and the mechanisms involved in the pathophysiology of diabetic nephropathy.

\section{AGEs}

AGEs are mainly formed non-enzymatically by the interaction of reducing sugars (glucose, glucose-6-phosphate, and fructose) with free amino groups of proteins (more often lysine and arginine), lipids, and nucleic acids, through complex and sequential reactions known as the Maillard reaction ${ }^{22}$. Under hyperglycemic and/or oxidative stress conditions, this process begins with the conversion of reversible Schiff base adducts to more stable, covalently bound Amadori rearrangement products. Over the course of days to weeks, these Amadori products undergo further rearrangement reactions to form AGEs, irreversibly ${ }^{2}$. As glycation depends only on glucose concentration, this explains AGEs enhancement in $\mathrm{DM}^{23}$. Decreased serum AGEs clearance may further increase tissue AGEs accumulation. Other factors that influence AGEs accumulation are: hyperglycemia duration, oxidative stress, inflammation, reduced kidney function and $\operatorname{diet}^{24,25}$.

Alternatively, AGEs can derive from highly reactive dicarbonyl such as glyoxal, methylglyoxal and 3-deoxiglucosone. Methylglyoxal - the main AGE precursor- is formed from the spontaneous dephosphorylation of triose phosphates during anaerobic glycolysis, spontaneously fragmentation of a Schiff base during the Maillard reaction and from ketone and threonine metabolism. These compounds may be known as products of advanced lipoxidation ${ }^{26}$. In metabolic syndrome, the combination of glucose intolerance, dyslipidemia, hypertension, and insulin resistance may generate more AGEs for synergic effect through both glycation and lipoxidation pathways ${ }^{27}$.

In general, the damage associated to AGEs accumulation involves three basic mechanisms: 1) modification in protein structures involved in gene transcription; 2) interaction with extracellular matrix proteins which alters the signaling between the cell and the matrix; 3 ) changes in serum lipids and proteins that can bind to specific receptors, stimulating production of inflammatory cytokines and intracellular growth factors. In mesangial cells of the renal glomerulus, the cross-linking between collagen, AGEs and lysine and/or arginine residues of protein can contribute to rigidity, loss of elasticity, increased resistance to proteolysis, inhibition of tissue remodeling and thickening of the glomerular capillary membrane leading to changes such as glomerular sclerosis ${ }^{28}$.

Vascular cell dysfunction related to AGEs accumulation can be due to its interaction with proteins, forming stable and irreversible bonds. Moreover, AGEs bioavailability depends on the half-life of the proteins $^{29}$. This explains why the main sites of DM chronic complications are tissues where proteins have longer half-lives, such as proteins of the glomerular basement membrane and lens, featuring nephropathy and retinopathy, respectively. Importantly, chronic kidney disease occurs where long-lived proteins are present, such as glomerular basement membrane ${ }^{30}$. On the other hand, bonds to other types of proteins with shorter half-lives are unstable, leading to rapid AGEs degradation followed by renal excretion ${ }^{29}$.

Increased intracellular glucose is related to pathophysiological mechanisms that trigger DM chronic complications ${ }^{31}$. These mechanisms include: 1) Stimulation of the polyol pathway: in the persistent hyperglycemia, part of the glucose is converted to sorbitol, which increases ROS production, leading to cell dysfunction ${ }^{29}$. 2) Activation of protein kinase $C$ (PKC) isoforms, which induce the synthesis of diacylglycerol, fibronectin, collagen type IV, contractile proteins, and extracellular matrix protein genes in endothelial cells and neurons ${ }^{29,31}$. 3) Activation of hexosamine pathway, which may interfere with the glycosylation of proteins, changing their final structure and also altering gene expression. 4) Increase of intracellular AGEs levels leads to increase glycation of plasmatic and extracellular matrix proteins. The effects of AGE accumulation in the body can be attributed to the crosslinking of extracellular matrix proteins, which leads to alteration of the cell structure ${ }^{28,32}$.

The four pathways described are the result of persistent hyperglycemia and converge in the formation of AGEs, with formation of ROS, mainly superoxide anion, contributing to altering intracellular redox status, leading to oxidative stress ${ }^{29,30,33}$. Therefore, the increased ROS in DM, together with the reduction of antioxidant defenses are related to the onset of diabetic complication ${ }^{31,33,34}$. ROS increase leads to DNA breaking, which activates poly ADP-ribose polymerase (PARP), reducing the 
activity of glyceraldehyde-3-phosphate (GAPDH), a key enzyme in the glycolytic pathway, which, in turn, activates the polyol pathway, increases the formation of AGEs, PKC activation, and increases the flow of hexosamines ${ }^{35}$.

Thus, there seems to be a cyclic activation of AGEs through increased ROS, suggesting the induction of a ROS-AGE-RAGE pathway. In this context, the increased $\mathrm{O}_{2}$ - production by the electron transport chain appears to be the link between oxidative stress, AGE, and diabetes complications ${ }^{30,33,34}$. However, the mechanism by which the increased $\mathrm{O}_{2}$ - production resulting from hyperglycemia is related to tissue damage that results in diabetic complications still needs to be elucidated.

The mechanism of action of AGEs in target cells involves the interaction with its receptor (RAGE). RAGE is a member of the immunoglobulin superfamily of cell transmembrane surface molecules, playing key roles in the pathogenesis of diabetic complications. The binding of AGE to RAGE induces apoptosis in various cell types ${ }^{36}$ and causes endothelial dysfunction by increased oxidative stress and stimulates the release of cytokines and growth factors by macrophages, renal mesangial, and vascular endothelium, for example $24,33,35$. Growth factors can be involved in the complications of diabetes, as they are increased in hyperglycemia. Transforming Growth Factor Beta (TGF- $\beta$ ) is increased in diabetic nephropathy, stimulating production of collagen in the glomerular capillary membrane and fibronectin by mesangial cells. Other factors, such as platelet activating factor (PAF), epidermal growth factor (EGF), insulin-like growth factor 1 (IGF-1), growth hormone (GH) and insulin may play a role in $\mathrm{DM}$ complications ${ }^{29}$. This factors can in turn induce multiple signaling pathways that generate reactive oxygen species (ROS) ${ }^{3}$.

There is evidence that the AGE-RAGE interaction induces inflammatory responses and oxidative stress, leading to more AGE formation and accumulation, and hence to RAGE overexpression in diabetic patients. It is well known that the AGE-RAGE interaction leads to stimulation of intracellular signaling pathways whose target is the nuclear factor K $\beta$ (NF-K $\beta$ ). NF-K $\beta$ induces the transcription of proinflammatory genes and stimulates transcription of RAGE itself ${ }^{30,35,37}$. This positive feedback loop (AGE-RAGE) creates a vicious circle that may explain the phenomenon called metabolic memory in diabetic vascular complications, in which even after a period of glycemic control, vascular complications do not recede ${ }^{38}$. Apart its transmembrane localization, RAGE structure consist of a soluble isoform (sRAGE), formed by two processes: alternative splicing (endogenous secretory receptor for AGE (esRAGE) or proteolytic cleavage (cRAGE) mediated by disintegrins and metalloproteinases. Studies suggest that sRAGE are risk predictors for vascular complications and therapeutic targets for the prevention of DM complications ${ }^{38,39}$.

Quantification of glycation products is routinely analyzed through the measurement of glycated hemoglobin $(\mathrm{HbA} 1 \mathrm{c})$, which is used to assess metabolic control in diabetic patients ${ }^{8}$. HbA1c is caused by an irreversible reaction between glucose and the $\mathrm{N}$-terminal valine amino acid unit of the beta chain of hemoglobin ${ }^{40,41}$. In a non-diabetic individual, approximately $4 \%$ to $6 \%$ of total $\mathrm{HbA} 1 \mathrm{c}$ is glycated, whereas in patients with marked uncontrolled diabetes, this percentage can reach levels two to three times higher than normal. The rate of formation of this compound is directly proportional to the plasma glucose concentration. HbA1c levels above $7 \%$ are associated with a progressively increased risk of chronic complications, such as diabetes kidney disease ${ }^{8,42}$. In this sense, HbA1c dosage plays a key role in the monitoring of glycemic control in diabetic patients, since it provides information about the retrospective index of plasma glucose.

\section{DIABETIC KIDNEY DISEASE}

Among individuals with T2DM, about $20-40 \%$ will be affected by diabetic nephropathy, which is the leading cause of end-stage renal disease in these individuals ${ }^{21,30,35}$. The risk factors for onset and progression of diabetic nephropathy include familiar history, diabetes duration, hypertension, presence of retinopathy, smoking, and hypercholesterolemia ${ }^{29}$. Diabetic nephropathy is the leading cause of chronic kidney disease and is associated with increased risk of death from cardiovascular disease (CVD) ${ }^{19-43}$.

Hemodynamic changes in renal microcirculation plays an important role in the onset and progression of nephropathy ${ }^{29}$. These changes include glomerular hyperfiltration or hyperperfusion and increased glomerular pressure, where the glomerulus is the main focus of the lesion. ACE-inhibitor drugs such as angiotensin II receptor blockers have shown beneficial effect in preventing the progression of diabetic nephropathy by reducing intraglomerular pressure, dilating the efferent arteriole ${ }^{44,45}$.

Microvascular complications of T1DM and T2DM appear to be related to genetic susceptibility, as there are individuals who have the disease for a long time and never developed nephropathy or retinopathy and individuals with the same glycemic control who develop microvascular complications. Also, the risk of diabetic nephropathy development increase in individuals who have relatives with T1DM with diabetic 
nephropathy ${ }^{38,39}$. Thus, genetic susceptibility may affect the development of complications.

Among the metabolic factors, hyperglycemia is the major determinant in the onset and progression of diabetic nephropathy ${ }^{19,39}$. Renal mesangial cells activated by AGEs induce excess extracellular matrix, which would explain the structural changes in the glomerulus, such as, mesangial expansion that occurs in diabetes and other renal diseases ${ }^{18,30}$. In vitro studies with mesangial cells cultured in hyperglycemic condition demonstrated increased expression of collagen type IV, and its accumulation is proportional to the degree of glomerular sclerosis ${ }^{28,30}$. In sclerotic glomerulus there is also accumulation of collagen types I and III, which are not usually seen in healthy glomeruli 29,30 . Mesangial cells cultured in hyperglycemic conditions showed increased expression of GLUT1, which is the main glucose transporter in mesangial cells $s^{46,47}$. In addition, these cells showed higher PKC activity and the subsequent stimulation of extracellular matrix proteins expression ${ }^{47,48}$. The increased expression of GLUT1 in vitro up regulated GLUT1 expression, through the activation of PKC and promoted the stimulation of extracellular matrix synthesis in mesangial cells. The expression of GLUT1 seems to be the limiting step for the use of glucose by mesangial cells ${ }^{48,49}$.

Angiotensin II (AII) also increases the expression of messenger RNA (mRNA) of GLUT1 in mesangial cells and GLUT2 (responsible for tubular reabsorption of glucose) also favored increased interstitial glucose, which is transported intracellularly by GLUT1 ${ }^{48,49}$. The production of All mesangial cells under glucose stimulation leads to an intracrine action within the cells, mediating inflammatory and proliferative effects, with consequent cell proliferation, matrix expansion, and inflammation, contributing directly to the glomerular sclerosis observed in diabetic nephropathy ${ }^{50}$. Thus, glucose and angiotensin II seem to have similar effects on cultured mesangial cells, promoting cell growth, proliferation, extracellular matrix and inhibiting their degradation. Possibly by using similar signal transduction pathways, glucose and IIA can ultimately lead to an increase in cellular production of TGF- $\beta^{50-53}$.

Oxidative stress, especially nitric oxide (NO) accumulation, is related to the onset of diabetic nephropathy ${ }^{2}$, although the mechanism by which its accumulation is related to kidney damage is still poorly understood. However, nitric oxide acts as a physiological regulator of arterial blood pressure and of mesangial cells proliferation ${ }^{2,54}$. Moreover, its accumulation is involved in early and in late-stage renal disease ${ }^{52,54}$. Nitric Oxide has a very short half-life and is formed from L-arginine, in an oxidation reaction catalyzed by three nitric oxide synthases isoforms (NOS) ${ }^{55,56}$. Two NOS are calcium dependent, one expressed in endothelial cells (eNOS) and the other in neuronal cells (nNOS). The third isoenzyme is independent of calcium, but induced by inflammatory or immune response, and is widely expressed (iNOS). The NO's mechanism of action consists on its diffusion through the cell membrane and activation of a second messenger, guanylate cyclase, which acts on various target cell proteins by activating protein kinase cascades, including the mitogen-activated protein kinase (MAPK) and c-Jun $\mathrm{N}$-terminal kinases (JNK) pathways ${ }^{57}$. Intracellular responses unleash important physiological effects, such as being a potent vasodilator with effects on both blood pressure regulation and renal function ${ }^{2,54}$.

Recent studies have shown that AGEs induce iNOS expression in mesangial cells by activation of cytokines 2 - NF-kB and p38 MAPK ${ }^{54,56}$. Mesangial cells cultured in high glucose medium showed an increase in iNOS expression related to expansion of extracellular fibronectin ${ }^{52,53,55}$. Moreover, in glomeruli isolated from diabetic animals, there was a correlation between PKC activation and suppression of nitric oxide $^{53}$. It was shown in a two-week experimental diabetes animal model induced by streptozotocin, an increased in eNOS expression in both the afferent arteriole and glomerule, leading to an increase in glomerular hyperperfusion, contributing to the initiation of diabetic nephropathy ${ }^{55}$. In mesangial cells cultured in high glucose medium, it was shown an increase in the expression of both iNOS mRNA and protein via activation of PKC, promoting accumulation of extracellular matrix, corroborating in vivo assessments ${ }^{54,55}$.

The increased expression of iNOS is generally associated to the inflammatory process that accompanies diabetic nephropathy, having no participation in normal renal hemodynamics. Moreover, the eNOS found in glomerular endothelial cells contributes significantly with nitric oxide to normal kidney function and can be involved in the early stages of nephropathy ${ }^{55-57}$.

The importance of NFKB as a common mediator in the functional and structural changes observed in the pathophysiology of diabetes kidney disease is increasingly well established ${ }^{58}$. NFkB can be activated by hyperglycemia among other mediators such as cytokines, oxidant molecules, AGEs and angiotensin II, which are increased in diabetes. Experimental and human studies have shown increased NFKB activation and increased expression of proinflammatory genes in endothelial cells, vascular smooth muscle cells, and proximal tubule cells, correlated with renal cell infiltration and magnitude of proteinuria in patients with diabetes ${ }^{59,60}$. After activation, NFKB induces the 
transcription of a number of genes, including adhesion molecules, cytokines, and nitric oxide synthase, among other inflammatory proteins involved in the pathogenesis of the renal complications of diabetes ${ }^{59-61}$.

In patients with insulin-dependent diabetes, intensive insulin therapy (insulin pump or three or more daily injections) for the control of blood glucose levels can reduce the frequency and severity of nephropathy. Intensive therapy reduces the occurrence of microalbuminuria up to $39 \%$ and albuminuria in $54 \%$ of cases, compared to conventional therapy. The main adverse effect associated with intensive therapy is the increased occurrence of severe hypoglycemia 8,16 .

Some evidence demonstrates that AGEs play a pivotal role in the development and progression of diabetic vascular damage. The attenuation of AGE formation and/or inhibition of RAGE activation manifests in improved renal function. All compounds have been evaluated for their anti-AGE effects and are classified as 1) anti-AGEs that prevent AGE formation, 2) AGE breakers that break preformed AGEs and Amadori products, 3) RAGE inhibitors, 4) redox regulators, and 5) neutraceuticals that serve as anti-glycating agents ${ }^{62-64}$.

Pimagedine (also known as aminoguanidine) inhibited the formation of AGEs and slowed the progression of diabetic complications in animal models. Pyridoxamine, the natural form of pyridoxine (vitamin B6), also prevents AGE formation. AGE breakers include AGE-detoxifying enzymes and small chemical molecules that are able to recognize and break the Amadori products or AGE crosslinks. An example is ALT - 771. Studies with this molecule suggested the pharmacological potential of these molecules in preventing AGE-mediated diabetic complications. The use of RAGE inhibitors such as pravastatin, curcumin could be a potential strategy to combat AGE-mediated adverse cellular manifestations. The rate of conversion of reversible Schiff's base and partially reversible Amadori products to AGEs is accelerated in oxidative stress conditions. The use of antioxidants such as lipoic acid, vitamin $E$, and ubiquinol or redox regulators may to prevent AGE-mediated cellular toxicity ${ }^{62,63}$. However, new agents in treatment of diabetic complications required more studies to be validated.

\section{CONCLUSIONS}

The prevalence of DM has increased considerably worldwide and recent estimates suggest an even greater progression, associated with the epidemic of overweight and obesity. As a model of chronic disease, its complications significantly affect the quality of life of diabetic patients, configuring a public health problem ${ }^{1,7}$.

Diabetic nephropathy has been widely recognized as one of the major complications of type 2 diabetes mellitus, being a more common cause of chronic end-stage renal disease ${ }^{11}$. It is functionally characterized by proteinuria and albuminuria and pathologically by glomerular hypertrophy, mesangial expansion, and tubulointerstitial fibrosis.

The main mechanism involved in diabetic nephropathy occurs due to the excessive formation of AGEs, which are physiopathologically based on hyperglycemia. The AGE-RAGE interaction increases the formation of ROS and RNS, altering the redox state and causing oxidative stress, which contributes to the development and progression of diabetes and related complications. Another consequence of this interaction is increased expression of inflammatory mediators and, consequently, cell injury ${ }^{30,35,37}$.

Avoiding the installation as well as the progression of this complication is of paramount importance to improve the prognosis in diabetic patients. Diabetic kidney disease may be present at diagnosis of T2DM or after 5 years of T1DM, and renal injury screening under these circumstances is recommended by albuminuria using the albumin/creatinine ratio in a random urine sample. Studies have shown that intensive blood glucose control significantly reduces the risk of complications, including nephropathy. In addition, other effective strategies are the remission of proteinuria in these patients, which may be obtained by the use of drugs with potentially nephroprotective properties such as angiotensin converting enzyme (ACE) inhibitors or angiotensin II receptor blockers (BRA II), as well as by the control of cardiovascular risk factors, such as dyslipidemia, hypertension, and obesity ${ }^{65}$. Additional potential therapies for diabetic kidney disease have been or are currently being evaluated 62,63 .

\section{REFERENCES}

1. Shaw JE, Sicree RA, Zimmet PZ. Global estimates of the prevalence of diabetes for 2010 and 2030. Diabetes Res Clin Pract. 2010;87(1):4-14. PMid:19896746. http://dx.doi. org/10.1016/j.diabres.2009.10.007.
2. Yamagishi S, Matsui T. Nitric oxide, a janus-faced therapeutic target for diabetic microangiopathy-Friend or foe? Pharmacol Res. 2011;64(3):18794. PMid:21635951. http://dx.doi. org/10.1016/j.phrs.2011.05.009.
3. Zhu Y, Shu T, Lin Y, Wang H, Yang J, Shi $Y$, et al. Inhibition of the receptor for advanced glycation end products (RAGE) protects pancreatic $\beta$-cells. Biochem Biophys Res Commun. 
2011;404(1):159-65. PMid:21111711. http://dx.doi.org/10.1016/j. bbrc.2010.11.085.

4. DeFronzo RA. From the Triumvirate to the Ominous Octet: a new paradigm for the Treatment of Type 2 Diabetes Mellitus. Diabetes. 2009;58(4):77395. PMid:19336687. http://dx.doi. org/10.2337/db09-9028.

5. Brownlee M. Biochemistry and molecular cell biology of diabetic complications. Nature. 2001;414(6865):813-20. PMid:11742414. http://dx.doi. org/10.1038/414813a.

6. Curtis PJ, Potter J, Kroon PA, Wilson $\mathrm{P}$, Dhatariya K, Sampson $M$, et al. Vascular function and atherosclerosis progression after 1 $y$ of flavonoid intake in statin-treated postmenopausal women with type 2 diabetes: a double-blind randomized controlled trial. Am J Clin Nutr. 2013;97(5):936-42. PMid:23553151. http://dx.doi.org/10.3945/ ajcn.112.043745.

7. Qazi MU, Malik S. Diabetes and cardiovascular disease: original insights from the framingham heart study. Glob Heart. 2013;8(1):438. PMid:23544179. http://dx.doi. org/10.1016/j.gheart.2012.12.008.

8. Nathan DM, Genuth S, Lachin J, Cleary P, Crofford O, Davis M, et al., Diabetes Control and Complications Trial Research Group. The effect of intensive treatment of diabetes on the development and progression of long term complications in insulindependent diabetes mellitus. $N$ Engl J Med. 1993;329(14):97786. PMid:8366922. http://dx.doi. org/10.1056/NEJM199309303291401.

9. Scialla JJ, Kao WH, Crainiceanu C, Sozio SM, Oberai PC, Shafi T, et al. Biomarkers of vascular calcification and mortality in patients with ESRD. Clin J Am Soc Nephrol. 2014;9(4):74555. PMid:24458076. http://dx.doi. org/10.2215/CJN.05450513.

10. Li J, Wu HM, Zhang L, Zhu B, Dong BR. Heparin and related substances for preventing diabetic kidney disease. Cochrane Database Syst Rev. 2010;(9):CD005631. PMid:20824845.

11. American Diabetes Association. Standards of Medical Care in Diabetes - 2017. Diabetes Care. 2017;40(Suppl 1):S1-135. PMid:27979885.
12. Harwell TS, Nelson RG, Little RR, McDowall JM, Helgerson SD, Gohdes D. Testing for microalbuminuria in 2002: barriers to implementing current guidelines. Am J Kidney Dis. 2003;42(2):245-8. PMid:12900804. http://dx.doi.org/10.1016/S02726386(03)00648-6.

13. Vivian E, Mannebach C. Therapeutic approaches to slowing the progression of diabetic nephropathy - is less best? Drugs Context. 2013;2013:212249.

14. Tan J, Jaung R, Gamble G, Cundy $T$. Proteinuric renal disease in type 2 diabetes-is remission of proteinuria associated with improved mortality and morbidity? Diabetes Res Clin Pract. 2014;103(1):6370. PMid:24380605. http://dx.doi. org/10.1016/j.diabres.2013.11.023.

15. Newman DJ, Mattock MB, Dawnay $A B$, Kerry S, McGuire A, Yaqoob $M$, et al. Systematic review on urine albumin testing for early detection of diabetic complications. Health Technol Assess. 2005;9(30):iii-vi, xiii-163.

16. Parving $\mathrm{HH}$, Mogensen $\mathrm{CE}$, Thomas MC, Brenner BM, Cooper ME. Poor prognosis in proteinuric type 2 diabetic patients with retinopathy: insights from the RENAAL study. QJM. 2005;98(2):119-26. PMid:15655096. http://dx.doi.org/10.1093/qjmed/ hci017.

17. Chen FQ, Wang J, Liu XB, Ma XY, Zhang $X B$, Huang, $T$, et al. Levels of inflammatory cytokines in type 2 diabetes patients with different urinary albumin excretion rates and their correlation with clinical variables. $J$ Diabetes Res. 2013;2013:138969.

18. Vlassara H, Palace MR. Diabetes and advanced glycation endproducts. $J$ Intern Med. 2002;251(2):87101. PMid:11905595. http:// dx.doi.org/10.1046/j.13652796.2002.00932.x.

19. Guimarães EL, Empsen C, Geerts A, van Grunsven LA. Advanced glycation end products induce production of reactive oxygen species via the activation of NADPH oxidase in murine hepatic stellate cells. J Hepatol. 2010;52(3):38997. PMid:20133001. http://dx.doi. org/10.1016/j.jhep.2009.12.007.

20. Penno G, Solini A, Bonora E, Fondelli C, Orsi E, Zerbini G, et al., Renal Insufficiency And Cardiovascular Events (RIACE) study, group.
Gender differences in cardiovascular disease risk factors, treatments and complications in patients with type 2 diabetes: the RIACE Italian multicentre study. J Intern Med. 2013;274(2):176-91. PMid:23565931. http://dx.doi.org/10.1111/joim.12073.

21. Penno G, Solini A, Zoppini G, Orsi E, Fondelli C, Zerbini G, et al., Renal Insufficiency and Cardiovascular Events (RIACE) Study Group. Hemoglobin A1c variability as an independent correlate of cardiovascular disease in patients with type 2 diabetes: a cross-sectional analysis of the renal insufficiency and cardiovascular events (RIACE) Italian multicenter study. Cardiovasc Diabetol. 2013;12(1):98. PMid:23829205. http://dx.doi. org/10.1186/1475-2840-12-98.

22. Robert L, Labat-Robert J. Role of the Maillard reaction in aging and age-related diseases. Studies at the cellular-molecular level. Clin Chem Lab Med. 2014;52(1):510. PMid:23492562. http://dx.doi. org/10.1515/cclm-2012-0763.

23. Delgado-Andrade C. Maillard reaction products: some considerations on their health effects. Clin Chem Lab Med. 2014;52(1):53-60. PMid:23612540. http://dx.doi.org/10.1515/cclm-20120823.

24. Gradinaru D, Borsa C, lonescu C, Margina D. Advanced oxidative and glycoxidative protein damage markers in the elderly with type 2 diabetes. J Proteomics. 2013;92:31322. PMid:23587667. http://dx.doi. org/10.1016/j.jprot.2013.03.034.

25. Yamagishi S. Advanced glycation end products (AGEs) and their receptor (RAGE) in health and disease. Curr Pharm Des. 2008;14(10):939. PMid:18473842. http://dx.doi.org/10.2 174/138161208784139756.

26. Masterjohn C, Park Y, Lee J, Noh SK, Koo SI, Bruno RS. Dietary fructose feeding increases adipose methylglyoxal accumulation in rats in association with low expression and activity of glyoxalase-2. Nutrients. 2013;5(8):3311-28. PMid:23966111. http://dx.doi.org/10.3390/nu5083311.

27. Cai W, Gao QD, Zhu L, Peppa M, He C, Vlassara H. Oxidative stressinducing carbonyl compounds from common foods: novel mediators of cellular dysfunction. Mol Med. 2002;8(7):337-46. PMid:12393931. 
28. Hornigold N, Johnson TS, Huang L, Haylor JL, Griffin M, Mooney A. Inhibition of collagen I accumulation reduces glomerulosclerosis by a Hic-5-dependent mechanism in experimental diabetic nephropathy. Lab Invest. 2013;93(5):553-65. PMid:23508044. http://dx.doi. org/10.1038/labinvest.2013.42.

29. Habib SL. Alterations in tubular epithelial cells in diabetic nephropathy. J Nephrol. 2013;26(5):865-9. PMid:24052469. http://dx.doi. org/10.5301/jn.5000287.

30. Oleniuc M, Secara I, Onofriescu M, Hogas S, Voroneanu L, Siriopol $\mathrm{D}$, et al. Consequences of advanced glycation end products accumulation in chronic kidney disease and clinical usefulness of their assessment using a noninvasive technique - Skin Autofluorescence. Maedica (Buchar). 2011;6(4):298-307. PMid:22879845.

31. Rørtveit R, Eggertsdóttir AV, Thomassen R, Lingaas F, Jansen JH. A clinical study of canine collagen type III glomerulopathy. BMC Vet Res. 2013;9(1):218. PMid:24156559. http:// dx.doi.org/10.1186/1746-6148-9-218.

32. Forbes JM, Cooper ME. Mechanisms of diabetic complications. Physiol Rev 2013;93(1):137-88. PMid:23303908. http://dx.doi.org/10.1152/ physrev.00045.2011.

33. Morita M, Yano S, Yamaguchi T, Sugimoto T. Advanced glycation end products-induced reactive oxygen species generation is partly through NF-kappa B activation in human aortic endothelial cells. J Diabetes Complications. 2013;27(1):115. PMid:22944044. http://dx.doi. org/10.1016/j.jdiacomp.2012.07.006.

34. Afanas'ev I. Signaling of reactive oxygen and nitrogen species in diabetes mellitus. Oxid Med Cell Longev. 2010;3(6):361-73. PMid:21311214. http://dx.doi. org/10.4161/oxim.3.6.14415.

35. Goh SY, Cooper ME. Clinical review: The role of advanced glycation end products in progression and complications of diabetes. J Clin Endocrinol Metab. 2008;93(4):114352. PMid:18182449. http://dx.doi. org/10.1210/jc.2007-1817.

36. Lim M, Park L, Shin G, Hong H, Kang I, Park Y. Induction of apoptosis of beta cells of the pancreas by advanced glycation end-products, important mediators of chronic complications of diabetes mellitus. Ann N Y Acad Sci. 2008;1150(1):3115. PMid:19120318. http://dx.doi. org/10.1196/annals.1447.011.

37. Yamamoto Y, Kato I, Doi T, Yonekura $\mathrm{H}$, Ohashi S, Takeuchi M, et al. Development and prevention of advanced diabetic nephropathy in RAGE-overexpressing mice. J Clin Invest. 2001;108(2):2618. PMid:11457879. http://dx.doi. org/10.1172/JCl11771.

38. Jules J, Maiguel D, Hudson BI. Alternative splicing of the RAGE cytoplasmic domain regulates cell signaling and function. PLoS One. 2013;8(11):e78267. PMid:24260107. http://dx.doi.org/10.1371/journal. pone. 0078267 .

39. Oliveira MIA, Souza EM, Pedrosa FO, Réa FR, Alves ASC, Picheth $G$, et al. RAGE receptor and its soluble isoforms in diabetes mellitus complications. J Bras Patol Med Lab. 2013;49(2):97-108. http://dx.doi.org/10.1590/S167624442013000200004.

40. Peterson KP, Pavlovich JG, Goldstein D, Little R, England J, Peterson CM. What is hemoglobin A1c? An analysis of glycated hemoglobins by electropray ionization mass spectrometry. Clin Chem. 1998;44(9):1951-8. PMid:9732983.

41. Brownlee M, Cerami A, Vlassara $\mathrm{H}$. Advanced glycosylation end products in tissue and the biochemical basis of diabetic complications. $N$ Engl J Med. 1988;318(20):131521. PMid:3283558. http://dx.doi. org/10.1056/NEJM198805193182007.

42. UK Prospective Diabetes Study (UKPDS). Intensive blood glucose control with sulphonylureas or insulin compared with conventional treatment and risk of complications in the patients with type 2 diabetes (UKPDS 33). Group. Lancet. 1998;352(9131):83753. PMid:9742976. http://dx.doi. org/10.1016/S0140-6736(98)07019-6.

43. Scott D. Treatment of type 2 diabetes in chronic kidney disease: a case for linagliptin in the treatment of diabetes in severe renal impairment. Diabetes Metab Syndr Obes. 2013;6:35963. PMid:24124385. http://dx.doi. org/10.2147/DMSO.S51795.
44. Wylie EC, Satchell SC. Diabetic nephropathy. Clin Med (Lond). 2012;12(5):480-2, quiz 483-5. PMid:23101153. http://dx.doi. org/10.7861/clinmedicine.12-5-480.

45. Jay D, Hitomi H, Griendling KK. Oxidative stress and diabetic cardiovascular complications. Free Radic Biol Med. 2006;40(2):18392. PMid:16413400. http:// dx.doi.org/10.1016/j. freeradbiomed.2005.06.018.

46. Wang Y, Heilig K, Saunders T, Minto A, Deb DK, Chang A, et al. Transgenic overexpression of GLUT1 in mouse glomeruli produces renal disease resembling diabetic glomerulosclerosis. Am J Physiol Renal Physiol. 2010;299(1):F99111. PMid:20375117. http://dx.doi. org/10.1152/ajprenal.00466.2009.

47. Magier Z, Jarzyna R. The role of glucose transporters in human metabolic regulation. Postepy Biochem. 2013;59(1):70-82. PMid:23821945.

48. Heilig CW, Deb DK, Abdul A, Riaz $\mathrm{H}$, James LR, Salameh J, et al. GLUT1 regulation of the pro-sclerotic mediators of diabetic nephropathy Am J Nephrol. 2013;38(1):3949. PMid:23817135. http://dx.doi. org/10.1159/000351989.

49. Schaan BD, Irigoyen MC, Bertoluci MC, Lima NG, Passaglia J, Hermes $E$, et al. Increased urinary TGF- $\beta 1$ and cortical renal GLUT1 and GLUT2 levels: additive effects of hypertension and diabetes. Nephron Physiol. 2005;100(3):43-50. PMid:15855808. http://dx.doi.org/10.1159/000085413.

50. Leehey DJ, Singh AK, Alavi N, Singh R. Role of angiotensin II in diabetic nephropathy. Kidney Int Suppl. 2000;77:S93-8. PMid:10997697. http://dx.doi.org/10.1046/j.15231755.2000.07715.x.

51. Nose A, Mori Y, Uchiyama-Tanaka Y, Kishimoto N, Maruyama K, Matsubara $\mathrm{H}$, et al. Regulation of glucose transporter (GLUT1) gene expression by angiotensin II in mesangial cells: involvement of HB-EGF and EGF receptor transactivation. Hypertens Res. 2003;26(1):6773. PMid:12661915. http://dx.doi. org/10.1291/hypres.26.67.

52. Vidotti DB, Casarini DE, Cristovam PC, Leite CA, Schor N, Boim MA. High glucose concentration stimulates intracellular renin activity 
and angiotensin II generation in rat mesangial cells. Am J Physiol Renal Physiol. 2004;286(6):F103945. PMid:14722017. http://dx.doi. org/10.1152/ajprenal.00371.2003.

53. Tang SC, Lai KN. The pathogenic role of the renal proximal tubular cell in diabetic nephropathy. Nephrol Dial Transplant. 2012;27(8):304956. PMid:22734110. http://dx.doi. org/10.1093/ndt/gfs260.

54. Araujo M, Welch WJ. Oxidative stress and nitric oxide in kidney function. Curr Opin Nephrol Hypertens. 2006;15(1):72-7. PMid:16340670. http://dx.doi.org/10.1097/01. mnh.0000191912.65281.e9.

55. Veelken R, Hilgers KF, Hartner A, Haas A, Böhmer KP, Sterzel RB. Nitric oxide synthase isoforms and glomerular hyperfiltration in early diabetic nephropathy. J Am Soc Nephrol. 2000;11(1):71-9. PMid:10616842.

56. Chang PC, Chen TH, Chang CJ, Hou CC, Chan P, Lee HM. Advanced glycosylation end products induce inducible nitric oxide synthase (iNOS) expression via a p38 MAPKdependent pathway. Kidney Int. 2004;65(5):1664-75. PMid:15086905. http://dx.doi.org/10.1111/j.15231755.2004.00602.x.
57. Khamaisi M, Keynan S, Bursztyn M, Dahan R, Reinhartz E, Ovadia H, et al. Role of renal nitric oxide synthase in diabetic kidney disease during the chronic phase of diabetes. Nephron Physiol. 2006;102(3-4):72-80. http:// dx.doi.org/10.1159/000089946.

58. Navarro-González JF, MoraFernández C, Fuentes MM, GarcíaPérez J. Inflammatory molecules and pathways in the pathogenesis of diabetic nephropathy. Nat Rev Nephrol. 2011;7(6):327-40. PMid:21537349. http://dx.doi. org/10.1038/nrneph.2011.51.

59. Mezzano S, Aros C, Droguett A, Burgos ME, Ardiles L, Flores $C$, et al. NF-KB activation and overexpression of regulated genes in human diabetic nephropathy. Nephrol Dial Transplant. 2004;19(10):2505-12. PMid:15280531. http://dx.doi.org/10.1093/ndt/gfh207.

60. Pieper GM, Haq RU Activation of nuclear factor-K-B in cultured endothelial cells by increased glucose concentration: prevention by calphostin C. J Cardiovasc Pharmacol. 1997;30(4):528-32. PMid:9335415. http://dx.doi.org/10.1097/00005344199710000-00019.

61. Yerneni KK, Bai W, Khan BV, Medford RM, Natarajan R. Hyperglycemia induced activation of nuclear transcription factor $\mathrm{KB}$ in vascular smooth muscle cells. Diabetes.
1999;48(4):855-64. PMid:10102704. http://dx.doi.org/10.2337/ diabetes.48.4.855.

62. Fernandez-Fernandez B, Ortiz A, Gomez-Guerrero C, Egido J. Therapeutic approaches to diabetic nephropathy--beyond the RAS. Nat Rev Nephrol. 2014;10(6):32546. PMid:24802062. http://dx.doi. org/10.1038/nrneph.2014.74.

63. Kumar Pasupulati A, Chitra PS, Reddy GB. Advanced glycation end products mediated cellular and molecular events in the pathology of diabetic nephropathy. Biomol Concepts. 2016;7(5-6):293-309. PMid:27816946. http://dx.doi.org/10.1515/bmc-20160021.

64. Bolton WK, Cattran DC, Williams ME, Adler SG, Appel GB, Cartwright $\mathrm{K}$, et al., ACTION I Investigator Group. Randomized trial of an inhibitor of formation of advanced glycation end products in diabetic nephropathy. Am J Nephrol. 2004;24(1):3240. PMid:14685005. http://dx.doi. org/10.1159/000075627.

65. Tuttle KR, Bakris GL, Bilous RW, Chiang JL, de Boer IH, GoldsteinFuchs J, et al. Diabetic kidney disease: a report from an ADA Consensus Conference. Diabetes Care. 2014;37(10):2864-83. PMid:25249672. http://dx.doi. org/10.2337/dc14-1296.

Received: Jun 26, 2017 Accepted: Aug 23, 2017 